\title{
Strengthening Ethics: A Faith Perspective on Educational Research
}

\author{
Imran Mogra ${ }^{1}$ (D)
}

Published online: 4 September 2017

(C) The Author(s) 2017. This article is an open access publication

\begin{abstract}
This article discusses ethical guidelines from the viewpoint of the teachings of Islam and, although not ostensibly different, finds parallels in the manner in which ethics could be conceptualised in the context of research in education. It seeks an alignment between ethics from the perspective of being a professional engaged in educational research with a personal significance based on one's belief, which takes a holistic notion of life. The aims of being ethical researchers seem to be shared in many ways: protection, honesty and integrity. However, there is an added dimension of being accountable to God. The article first locates research within the wider context of Higher Education. Thereafter, to facilitate an understanding of ethics, as viewed from the framework of the Qur'ān, it proceeds to consider the ethical requirements of a university in the West Midlands, England, as a case study to examine the congruence, if any, with some of the ethical teachings of Islam. Based on the preliminary research, this article argues that Muslim researchers in education should be cognisant that their responsibilities are wider. Firstly, they are stewards meaning that the care and well-being of others comes first. Stewardship is both a Biblical and Qur'ānic concept meaning to be guardians. Secondly, by conducting their research in ethical ways, it will mean that they will be performing good deeds. These are meritorious actions rewarded by God. It also clarifies to supervisors and ethics review committees the key principles which might inform the thinking of some researchers from the Muslim community and how their motivations would be ethical.
\end{abstract}

Keywords Academics $\cdot$ Education $\cdot$ Ethics $\cdot$ Faith $\cdot$ Islam $\cdot$ Research

\section{Introduction}

Ethics is a sophisticated concept and ethical behaviour is contextual; what is considered right or wrong may be based on the moral codes which regulate it. Since these moral codes vary,

Imran Mogra

Imran.mogra@bcu.ac.uk

1 Department of Early Years and Primary Education, School of Education, Faculty of Health, Education and Life Sciences, Birmingham City University, City North Campus, B42 2SU, Birmingham, UK 
people will look at ethics and think about them in different ways. Nevertheless, from whatever perspective a researcher considers ethics, they are important as they guide and support researchers to think through their beliefs, attitudes and, ultimately, their research conduct. They also help to expose some of the assumptions made at the design stages of a research project, and so, researchers are required to examine the appropriateness or inappropriateness of the decisions they make and actions they carry out in the field or at a desk. Ethics is concerned with the study of the principles and methods for distinguishing right from wrong, good from bad, and just from unjust (Haney and Lykes 2010; Yunanda and Abd. Majid 2011; Reeder 2011).

To support how researchers deal with ethical issues in their research, many institutions and professional bodies have established codes of conduct that reflect and represent their worldview, aims and objectives. One of the purposes of these guidelines is to assist the individuals belonging and working in these settings to conduct their affairs in appropriate ways so that individuals can be accountable and take responsibility for their actions and gain public confidence. For example, the British Educational Research Association's ethics and guidance documents are used by educational researchers and those active in many other disciplines (BERA 2011). As such, there are ethical codes which regulate psychologists (BPS 2009), lawyers (The Law Society 2015) and nurses (Goldsmith 2011). In relation to teaching, literature on its ethical and moral dimensions began to appear in the 1980s (Maxwell et al. 2016) and it is emphasised that educators are 'role models' (Lunenberg et al. 2007).

Some teacher educators in universities conduct research in a range of topics. They include Muslims, Christians, Hindus, Sikhs, Jews, atheists and humanists among others. For the purposes of ethical theory and principles determined for decision making, it is interesting to consider the approaches taken by academics from different religious communities and nonreligious traditions and to find out to what extent their traditions inform their ethical philosophy. As employees, the ethical requirements of their studies have to meet institutional requirements. However, from the perspective of the individual, it may be pertinent to ask what else could be informing their guiding principles and goals? It is argued that for some academics the teachings of their religious tradition may be a contributing factor in their overall philosophical stance on the subject of ethics in conducting research.

\section{Factors Influencing Ethical Perspectives}

Several studies have investigated the spheres of influence that impact on ethical decision making. Andolsen (1997) showed that religion has a positive influence on ethical decision making. The study by Conroy and Emerson (2004) supported the evidence that religion positively impacts upon individual ethical attitudes. Moreover, religiosity has also been regarded as a determinant in shaping ethical values. Kum-Lung and Teck-Chai (2010) explored the influence of self-identification of religiosity with ethical behaviour. Those who self-identified as religious had a positive attitude towards business ethics. They also showed that intrapersonal religiosity was a significant determinant to attitude towards business ethics but interpersonal religiosity was not. Niles and Barbour (2014) concluded that their survey findings supported existing literature in that religion had a positive impact on ethical decision making. However, they suggested that more data was needed to assess the impact of other spheres of influence such as the work environment, peers, education and family. It would also be interesting, they noted, to assess if specific religions have different impacts on ethical 
decision making (Niles and Barbour 2014). On the other hand, others may not relate their faith to research ethics and may keep them apart. At the same time, it is important not to assume that in practice believers in a religious tradition would necessarily follow the ethics of their respective religious tradition when conducting academic research. Thus, the degree to which these are related or can be separated is another key question (Fort 1996). There appears to be little in terms of the exploration of the relationship between ethics in educational research and ethics from the view point of Islam, though attempts have been made in other fields (Abdul Rahman 2003; Al-A'ali 2008; Abuznaid 2009; Alahmad and Dierickx 2015).

\section{Sources of Ethical Thinking and Practice}

The academic tradition has tended to rely on the concept of universalised rational subject and liberal humanism of individualistic perspectives which places the duty upon individuals to be ethical (Halse and Honey 2010; Hammersley and Traianou 2012; Brooks et al. 2014). Other traditions, including Christianity and Islam, have been part of this historical development in influencing principles and practices of ethics. For some Muslims, the identity of their religion impacts on their ethical conduct, and therefore, parallels need to be sought. Yunanda and Abd. Majid (2011) have argued that Islam with its divine values plays an important role to embed cognitive ethical values. It emphasises the unity of God, the accountability to God and the concept of maslahah (public benefits) to be the foundations of ethics (Yunanda and Abd. Majid 2011).

Ethical issues have been discussed extensively within education and in most other academic disciplines, at governmental level and in other agencies (Brooks et al. 2014). There are requirements for social researchers to submit their research to ethics boards (Haney and Lykes 2010). These institutional and professional ethical requirements for carrying out research are conceptualised and realised in many different ways (Breakwell et al. 2012; Bryman 2016; D’Cruz and Jones 2014; Gregory 2003; Harcourt et al. 2011). However, many have several common features. Nevertheless, there has been variance over time in how people have conceptualised ethics and, as a result, ethical practice has diversified due to many reasons including changes in the methods used by researchers and the evolution of ethical sensibilities. For the purpose of this article, it is important for all researchers to note that there are differences between countries and cultures in many domains of ethical principles (Brooks et al. 2014) and that they are not universal but mainly informed by western values and systems (Brooks et al. 2014).

In addition to these ethical approaches, as an academic who engages in educational research and who identifies himself as a Muslim researcher in education, it is important to be acquainted with Islamic ethical requirements so that they become both an additional and fundamental means of meeting both institutional and religious requirements. At the same time, it is required that a responsive researcher is ethical. Thus, when these two come together it becomes more powerful. Bringing such a religious perspective to research ethics may also be relevant for other researchers, as it may result in acknowledging other sources of ethics. This may usefully inform researchers and supervisors to view ethics from the viewpoints of the teachings of Islam. At the same time, all researchers may have an opportunity to see Muslim ethics from the point of view of their participants should they be Muslims. The aim of this paper, therefore, is to complement existing frameworks by treating the Qur'ān as an example of a source which informs ethical principles and practices. The central idea of this paper is to extend educational 
researchers' knowledge about the possible influence of scriptures on researchers so that they recognise that there may be other sources of influence in other faith traditions as well. For example, this has been usefully done in other academic disciplines. Al-A'ali (2008) evaluated and surveyed the teaching of the Association for Computing Machinery code of conduct from an Islamic point of view. Al-A'ali (2008) demonstrated that teaching computer ethics in general, and computer ethics from an Islamic point of view in particular, clearly contributed to ethical behaviour of Muslim IT professionals with regards to software development issues. The article also attempts to show that there is an alignment between ethics as required from a professional engaged in educational research, and a researchers' beliefs. Thus, for a Muslim researcher, this alignment might be personally significance as it gives a holistic notion to ethics and covers all aspects of life.

This article begins by locating research within the wider context of Higher Education. To facilitate an understanding of ethics, as seen within the framework of the Qur'ān, some of the ethical guidelines and requirements from the viewpoint of the teachings of Islam are considered and transferred to the context of research in education. The paper then proceeds to look at the ethical requirements of a university in the West Midlands, England, as a case study to examine the congruence, if any, with some of the ethical teachings of Islam. Thereafter, implications are discussed and a conclusion is presented.

\section{Research in Higher Education}

Academics are under greater pressure to conduct research and increase their outputs. One of the reasons for this is that their reputation and that of their institution and their income is linked to research activities. In such a context and in a culture of 'publish or perish' (Colquhoun 2011), it is imperative for researchers to reflect and continuously review ethical principles and practices which they adhere to and uphold, primarily to minimise harm to all concerned.

Universities are committed to providing both their staff and students with support to ensure that research is conducted to high ethical standards. However, research studies show there to be many areas and types of lapses that can occur in universities, including breaches in institutional ethics and the misconduct of research (Heyneman 2011). Kelley and Chang (2007) investigated what and where lapses in research ethics occurred in university settings and who they affected, acknowledging at the same time that the full range is unknown. However, they note that some researchers found that lapses took place due to employees putting their self-interests above honesty. Bruhn et al. (2002) also explored the intersection of ethics and professionalism among university members and offered a typology of ethics failure in academia. They stressed the need to reinforce what it means to be a professional and a good citizen in one's chosen profession. Rather than implementing more assessments and evaluations, they advocate an honest alignment between what researchers say they believe in with what they do to reduce incidents and the tolerance of ethics failure. Ethical standards are better served, according to Haney and Lykes (2010), through a concern for the underlying principles behind the guidelines for research with human subjects.

With the advent of social media and the subsequent availability of social media data sets, Zimmer (2010) outlined some ethical problems with a well-known Facebook case study. His aim was to use this case study to help expose the emerging challenges of engaging in research within online social network settings. He suggested that in the context of divulging personal information in social networking space, the notion of what constitutes "consent" [sic] needed 
to be further explored (Zimmer 2010, 323). He proposed that scholars engaging in research of this kind must recognise their own gaps in understanding the changing nature of privacy and the challenges of anonymising datasets. They must evaluate and educate various committees and others about the complexities of engaging in research on social networking sites, and finally, they must ensure that their research methods courses, codes of best practices and research protocols recognise the unique challenges of engaging in research on Internet and social media spaces (Zimmer 2010).

\section{Conceptualising Research Ethics in Islam}

For some Muslim educators, ethical conducts relating to education and research will emanate from the Qur'ān as well as disciplinary bodies as discussed above. In the Qur'ān, some ethical concepts have been defined through terms which include: goodness, rightness, truth, justice, piety, and their opposites such as, oppression, deception, and wrongdoing and others (Gwynne 2009; Maqsood 2010; 'Umaruddīn 1996). Those that are acceptable and considered good tend to have an umbrella term called sālihāt (good acts) whereas those rejected and denounced are termed sayyiāt (bad acts).

However, in the context of research ethics, it is also useful to recognise two other terms which determine the rulings on the actions carried out by Muslims. These are halāl (permitted) and haram (prohibited). Often, the application of these tends to be confined to and used for regulating diet. For example, intoxicants are categorised as harām, prohibited; whereas fruits are haläl, permitted. However, for some, these specific terms apply to all walks of life. Thus, a Muslim researcher would be expected to be cognisant of this in carrying out research by distinguishing what is permissible, i.e. ethical, and impermissible, i.e. unethical.

\section{Stewardship in Islam}

Education viewed from the perspective of Islam should be influenced by the way the totality of its social, political and religious systems is organised and the worldview that underpins it. Thus, to understand the ethical requirements which would guide a researcher in education or their educational research, it is useful to consider the status of humans and the responsibility given to them.

A fundamental source of ethics for some Muslims will be revelation, i.e., the Qur'ān. Islam is believed to be a complete way of life (Al-A'ali 2008), and therefore, ethical codes would have a wider remit. Muslims consider humans to be representatives of God (Qur'ān 1997 Chapter 2: verse 30). This status of humans is further elevated by the knowledge given and acquired by them and through which they are able to benefit materially and spiritually. Therefore, a Muslim is a steward and a trustee who will be accountable (Rahman 1980). This means that abuse and oppression of all kinds would be questionable. Therefore, in practice, humans are to use all materials for the betterment of social and economical spheres of life within this responsibility. In the light of the above, for research purposes, some ethical codes may take on a more holistic framework for Muslim researchers. In terms of accountability, responsibility and utility, a Muslim researcher would be expected to include consideration of God's wishes, in addition to those of their participants, funders, ethics review committees, gatekeepers and others. For those conducting research, the issue of maintaining relationships is not only familiar but also 
significant. Researchers are required to maintain good relationships with all concerned: supervisors, participants, stakeholders, publishers and others. The scope of this relationship becomes wider for a Muslim researcher as they would be expected to maintain their relationship with God in conducting their research by fulfilling their duties to God as well. Taken from this perspective, research related to education and other disciplines would be guided and conducted with universal values such as honesty, openness, integrity, truthfulness, justice and dignity.

\section{Methodology}

This research involved the study of a university policy concerning the ethical principles and procedures for conducting research. From the perspective of research methodology, as a form of qualitative social research method, documentary analysis is an important and invaluable research tool in its own right and in understanding social action (Mukherji and Albon 2015). Connolly (2016) maintains that this is particularly true in the area of education where educational settings have a wealth of documents. It is concerned with the investigation, analysis and interpretation of data generated from the study of documents and records by researchers to provide meaning around a particular relevant topic. The documents cover an extensive range of different kinds of sources, both public and private. The examination of this policy falls under the public domain category which can be used by organisational ethnographers as part of their study (Bryman 2016).

There is a range of problems faced by researchers carrying out documentary research which require consideration (Mukherji and Albon 2015). The policy is genuine and is considered authentic and meaningful, as it is clear and comprehensible to researchers. Nevertheless, it is important to recognise that the document is the work of a group of people who are credited with producing it, and, as such, it is likely to have a particular perspective which these people want to convey (Bryman 2016). The document has integrity and was considered credible as it was free from distortions and mistakes, being an official policy of the university produced for students and employees and publicly available with the aim of guiding research. Nevertheless, it cannot be regarded as giving an objective account of a state of affairs (Bryman 2016). In relation to its representativeness, it is noted that the policy does not represent the entirety of existing related documents on the subject which the ethics committee of the university might have.

There exists a surface and a deeper level of meaning in documents. The latter is achieved through analysis, interpretation and looking for the manner in which the discourse shapes the ideas about ethics, what is considered appropriate in a given situation and the role researchers play in conducting research (Woofitt 2008). The literal meaning has often concerned historians, whereas, sociologists uncover deeper meanings (Punch and Oancea 2014).

There are several ways of thinking about documentary analysis and many theoretical perspectives that can be applied (Punch and Oancea 2014). Based on key ethical teachings identified from the Qur'ān, an initial reading of the entire policy document was undertaken to identify and highlight comparable terms. In the second reading of the policy, specific terms denoting key ethical requirements were used as a framework to identify salient elements of the policy document and these were then related to their equivalents in the Qur'ān. Since further analysis was not required, these were not grouped to create categories.

There are obvious limitations to this method. The documents, being products of human activity, are positioned within the limitations of 'particular social, historical or administrative conditions and structures' and they 'depend on where they are used, by whom and to whom' 
(Punch and Oancea 2014:251). However, it is worth emphasising that the aim of this study was not to judge or assess the extent to which this policy conformed, or otherwise, to the Qur'ān, but rather, it sought possible alignments between the two sources of ethics.

\section{Institutional Ethics and Islam}

In this section, an examination of the ethical statements and requirements of a University, in the West Midlands, England, is carried out from the view of a Muslim educator using some of the teachings of the Qur'ān. The aim is twofold: to search for congruence, if any, so that confidence in conducting research based on these requirements is strengthened and add value to the conceptualisations of ethics in research.

There are five statements related to the conduct of and decisions made by staff at this University (BCU 2010). The University expects that staff will behave professionally and ethically in all its activities. This implies that staff and students who are engaged in research and other activities are aware of the ethical implications of such activities and are committed to discharging their responsibilities to the University, to clients and to research participants in an ethical manner, conforming to the highest professional standards of conduct. It recognises that issues of morality, safety and personal and institutional liability affect the University at many levels. Therefore, the University wants to be seen to be acting with propriety and care for the welfare of staff, students and the wider public. Thus, the practice of ethics is about conducting one's research in a disciplined manner within legal and other regulated constraints and with minimal impact on and detriment to others. It is, therefore, the responsibility of staff within the University to consider the ethical implications of their research, using the framework as a guide to fulfilling their obligations. In addition, it is the responsibility of faculties to ensure that staff and students are aware of their ethical obligations and that processes are in place to support them when elaborating methodologies, responding to the ethical requirements of funding bodies, or confronting ethical dilemmas.

In addition to the ethical statements above, there are four broad principles to implement within this University's ethical framework. Some of these relate to the ethical framework mentioned above. Below, these principles have been studied from the perspective of Islam. In addition to the above aims, the synthesis will attempt to demonstrate the degree of importance on various ethical issues and how they are realised by the University and the Islamic ethical system. One of the objectives is to show some of the common ground that exists between the two and, also, to present the ethical codes of Islam in the context of research so that the Muslim audience, in particular, is enabled to achieve higher levels of ethical commitment and thus have a broader effect on their conduct as researchers and professionals. For each ethical issue of the University, where applicable, at least one verse from the Qur'ān is presented. Otherwise, the ethical issues have been clustered to show their inclusion within these two.

The ethical requirements of the University state that:

Staff and students shall be made aware of their responsibilities and obligations to consider ethical issues arising from their research at or on behalf of the University.

In line with the above, the Qur'ān requires Muslims to honour their contracts. For example, it says "... and fulfil [every] commitment. Indeed, the commitment is ever [that about which one will be] questioned" (Qur'ān 1997 Chapter 17: verse 34). Hence, this is a manifest instruction to satisfy the contractual agreement that has been made. 
The dignity, rights, safety and well-being of participants must be the primary consideration in any research study.

Similar to the useful guidelines provided by BERA (2011), one can infer two points from the above ethical requirement: the research itself should not be harmful and the participants and/or co-researchers and any others involved in any capacity should have their dignity, rights, safety and well-being protected. Such a wide-ranging requirement is best encapsulated in a verse which is also comprehensive. The following verse counsels individuals against mischief: "And cause not corruption upon the earth after its reformation. And invoke [God] in fear and aspiration. Indeed, the mercy of [God] is near to the doers of good" (Qur'ān 1997 Chapter 7: verse 56). Therefore, research should not be used to spread mischief which includes dishonouring, harming, and infringing rights, and the promotion of the ill-being of others.

Informed consent is at the heart of ethical research.

Researchers gather data from their participants. This data is precious to these participants who are the actual owners and possessors of it as they may have acquired it through various means including study, transmission, experimentations and life experiences. In most cases, this knowledge is held by the possessors as something valuable either knowingly or unknowingly and so it is a kind of capital. In other words, their data could be considered to be a form of 'wealth'. Once data is conceived as being a valuable commodity belonging to participants, then, it should only be acquired by researchers from them with their permission. Along these lines, there is a verse which mentions two criteria that a person who wishes to take something from their rightful owner has to meet: justly and through mutual consent. The verse instructs: "O you who have believed, do not consume one another's wealth unjustly but only [in lawful] business by mutual consent. And do not kill yourselves [or one another]. Indeed, [God] is to you ever Merciful" (Qur'ān 1997 Chapter 4: verse 29). Hence, researchers have to obtain voluntary informed consent, preferably in written form, in a language understood by participants. Since this is a mutual agreement, participants should have a right to withhold their 'wealth', which they should be able to by withdrawing from the research at any time.

The ethical implications of research shall be assessed through a consideration of, for example: the sensitivity of any data that may be collected, with particular regard to matters such as age, colour, race/ethnicity, nationality, disablement, religion, sex, gender, sexual orientation, personal medical records and political beliefs;

In essence, the above is an attempt to ensure research is anti-discriminatory. Equity of all humans is a fundamental principle in the teachings of Islam. The Qur'ān (Chapter 7: verse 189) informs that humankind were created from a single pair (Hewer 2006). In addition, the significance of being just is reflected in the following verse: "O you who have believed, be persistently standing firm for [God], witnesses in justice, and do not let the hatred of a people prevent you from being just. Be just; that is nearer to righteousness. And fear [God]; indeed, [God] is Acquainted with what you do" (Qur'ān 1997 Chapter 5: verse 8).

the transparency to junior research staff and participants as to the purpose and possible uses of the research; the research methods and any risks involved; the confidentiality of information provided by research participants; the security and well-being of participants; the arrangements for the security of data; the arrangements for ensuring the anonymity of participants; 
Trust is a constant feature appearing in conventional ethical guidelines as well (BERA 2011; Brooks et al. 2014). It seems to be at the heart of meeting most, if not all, of the above ethical requirements. A researcher has to keep in trust all the information offered by the participant and, in turn, the participant expects the researcher to hold that information as a trust. Should the above requirements be viewed from such a perspective, then the Qur'ān has several incentives for being trustworthy. It praises those “...who are to their trusts and their promises attentive" (Qur'ān 1997 Chapter 23: verse 8) and it also states that: "Indeed, [God] commands you to render trusts to whom they are due and when you judge between people to judge with justice. Excellent is that which [God] instructs you. Indeed, [God] is ever Hearing and Seeing” (Qur'ān 1997 Chapter 4: verse 58).

whether any payments are to be made to the participants or other rewards granted and the integrity of that provision; whether any special indemnification arrangements may be required; the intellectual property rights of all those involved in the research, including research staff, research participants and the university; arrangements for the publication of research results, including issues of co-authorship and acknowledgement;

BERA (2011) has explicit guidelines on misconduct and requires all educational researchers not to bring research into disrepute. To meet the above ethical requirements, there are some inducements and directives from the Qur'ān which are relevant. In research terms, honesty is a cornerstone for researchers as they have to be honest with themselves, their participants and external bodies. It is a quality which is frequently mentioned in the Qur'ān. For example: "This is the Day when the truthful will benefit from their truthfulness" (Qur'ān 1997 Chapter 5: verse 119).

Researchers seldom plan and carry out their research in isolation, although some do. The Qur'ān emphasises the process of consultation, which can be applied to all aspects of research: "And those who have responded to their Lord and established prayer and whose affair is [determined by] consultation among themselves, and from what We have provided them, they spend" (Qur'ān 1997 Chapter 42: verse 38). Thus mutual arrangements need to be in place for property rights and funds.

Some educational researchers are provided with monetary funds, time and resources, internally and/or externally. This means that educational researchers have a responsibility to the community of researchers and to ensure this is met. BERA (2011) stipulates that all educational researchers must protect the integrity and reputation of educational research by ensuring they conduct their research to the highest standards. Therefore, care needs to be taken when using these provisions. One way of achieving this is for researchers to ensure they maintain their integrity at all times. For Muslim researchers this can be further enriched by knowing that all types of bribery are prohibited in the teachings of Islam: "And do not consume one another's wealth unjustly or send it [in bribery] to the rulers in order that [they might aid] you [to] consume a portion of the wealth of the people in sin, while you know [it is unlawful]" (Qur'ān 1997 Chapter 2: verse 188). These are additional safeguards for ethical practices which guard against all forms of abuse and assist in ensuring that the concept of stewardship is fully observed.

the desirability of an objective assessment being conducted of the ethical implications of the proposed academic activity by a competent person who has no direct association with it or the researcher(s) involved;

In carrying out the assessment, assessors of the ethical submission would need to be mindful of their professionalism and responsibility. In coming to a decision, the Qur'ān states: 
"Indeed, [God] commands you to render trusts to whom they are due and when you judge between people to judge with justice. Excellent is that which [God] instructs you. Indeed, [God] is ever Hearing and Seeing” (Qur'ān 1997 Chapter 4: verse 58).

the ethical issues/guidelines of any third party involved in the University's activities, such as professional bodies or providers of research funding.

The above ethical code might fall under agreements and contracts. A general guidance from the Qur'ān includes third party arrangements as indicated in the verse: "O you who have believed, do not betray [God] and the Messenger or betray your trusts while you know [the consequence]" (Qur'ān 1997 Chapter 8: verse 27).

\section{Research Implications}

This article has briefly considered some of the principles and guidelines from the viewpoint of the Qur'ān. From the viewpoint of my identity as a Muslim academic involved in educational research, ethics is integrated rather than separated. In the field of education, such a conception has some implications for Muslim researchers and their participants, in particular, as they conceive, execute and disseminate educational research. The paper has emphasised the expected behaviours of Muslims in the field of education and has also made other nonMuslim researchers aware of the Islamic codes of conduct which may guide Muslim research. It is anticipated that research supervisors, within the constraint of this paper, will become more familiar with the key principles of research ethics from the Islamic viewpoint and should be confident that, overall, the ethical requirements of research tend to fall under the remit of these guidelines. The Qur'ān, just like any other scripture, would feed into maintaining and supporting secular notions of ethics. Finally, this paper provides the foundations for future investigation emanating from this work within this important area of research in the field of education using the teachings of Islam. It has also pointed to further research on ethics among international students, in general, and trainee teachers in England, particularly in terms of what they understand by research ethics, what informs these understandings and the challenges, if any, they face in meeting ethical requirements in carrying out research.

\section{Conclusion}

This paper has attempted to align the methods of approaching ethics in educational research by discussing the ethical codes from the viewpoint of the teachings of Islam. After locating research within the wider context of Higher Education, it examined the ethical requirements of a University in England, as a case study and found some congruence with some of the ethical teachings of Islam.

Based on the preliminary research presented in this paper, Muslim researchers in education should be cognisant that their responsibilities are much wider. Firstly, they are stewards meaning the care and well-being of others comes first which is also a primary consideration in conventional ethics. Secondly, by conducting their research in ethical ways will mean that they will be performing good deeds. However, it is important to acknowledge that there will be other ways in which ethical principles and practices are conceptualised among Muslims. 
These ethical teachings demonstrate to supervisors and ethics review committees the key principles which might inform the thinking of some researchers from the Muslim community. On this basis, it is important to be aware that researchers from other faith backgrounds may also be informed by their own scriptures. Knowing this becomes relevant for opening up the avenues of understanding ethics from a wider perspective so that spiritual and holistic dimensions informed by religious ethics complement the conventions established in Higher Education institutions.

Open Access This article is distributed under the terms of the Creative Commons Attribution 4.0 International License (http://creativecommons.org/licenses/by/4.0/), which permits unrestricted use, distribution, and reproduction in any medium, provided you give appropriate credit to the original author(s) and the source, provide a link to the Creative Commons license, and indicate if changes were made.

\section{References}

'Umaruddīn, M. (1996). The ethical philosophy of al-Ghazālī. Delhi: Adam Publishers.

Abdul Rahman, A. (2003). Ethics in Accounting education: contribution of the Islamic principle of maslaha. IIUM Journal of Economics and Management, 11, 1-18.

Abuznaid, S. A. (2009). Business ethics in Islam: the glaring gap in practice. International Journal of Islamic and Middle Eastern Finance and Management, 2, 278-288.

Al-A'ali, M. (2008). Computer ethics for the computer professional from an Islamic point of view. Journal of Information, Communication \& Ethics in Society, 6, 28-45.

Alahmad, G., \& Dierickx, K. (2015). Paediatric research ethics: Islamic perspectives. British Journal of Medicine \& Medical Research, 5(9), 1158-1168.

Andolsen, B. (1997). Roman Catholic tradition and ritual and business ethics: A feminist perspective. Business Ethics Quarterly, 19,(2), 71-82.

BCU (2010). Birmingham City University's Research Ethical Framework. https://www.bcu.ac. uk/cmsproxyimage?path=/_media/docs/bcu-\%20research_ethical_framework.23.11.10.pdf. Accessed 17 Nov 2015.

BERA (2011). Ethical guidelines for educational research. London: British Educational Research Association. https://www.bera.ac.uk/wp-content/uploads/2014/02/BERA-Ethical-Guidelines-2011.pdf?noredirect=1. Accessed 14/11/2015.

BPS (2009). Code of Ethics and Conduct. Leicester: the British Psychological Society. Available at http://www. bps.org.uk/system/files/documents/code_of_ethics_and_conduct.pdf. Accessed 24 March 2016.

Breakwell, G., Smith, J. A., \& Wright, D. B. (2012). Research methods in psychology. London: SAGE.

Brooks, R., te Riele, K., \& Maguire, M. (2014). Ethics and education research. London: SAGE.

Bruhn, J. G., Zajac, G., Al-Kazemi, A., \& Prescott Jr., L. D. (2002). Moral positions and academic conduct: Parameters of tolerance for ethics failure. Journal of Higher Education, 73, 461-493.

Bryman, A. (2016). Social research methods (5th ed.). Oxford: Oxford University Press.

Colquhoun, D. (2011). Publish-or-perish: peer review and the corruption of science. The Guardian 05.09.2011. http://www.theguardian.com/science/2011/sep/05/publish-perish-peer-review-science. Accessed 14 Nov 2015.

Connolly, M. (2016). Selecting appropriate research methods for an educational context. In I. Palaiologou, D. Needham, \& T. Male (Eds.), Doing research in education: theory and practice (pp. 136-155). London: SAGE.

Conroy, S., \& Emerson, T. (2004). Business ethics and religion: Religiosity as a predictor of ethical awareness among students. Journal of Business Ethics, 50, 383-396.

D’Cruz, H., \& Jones, M. (2014). Social work research in practice: ethical and political contexts (2nd ed.). London: SAGE.

Fort, T. (1996). Religious belief, corporate leadership, and business ethics. American Business Law Journal, 33, $451-471$.

Goldsmith, J. (2011). The NMC code: conduct, performance and ethics. Nursing Times, 37, 12-14.

Gregory, I. (2003). Ethics in research. London: Continuum.

Gwynne, P. (2009). World religions in practice. Oxford: Oxford University Press.

Halse, C., \& Honey, A. (2010). Unravelling ethics: illuminating the moral dilemmas of research ethics. In W. Luttell (Ed.), Qualitative educational research (pp. 123-138). London: Routledge.

Hammersley, M., \& Traianou, A. (2012). Ethics in qualitative research: controversies and contexts. London: SAGE. 
Haney, W., \& Lykes, M. B. (2010). Practice, participatory research and creative research designs: the evolution of ethical guidelines for research. In W. Luttell (Ed.), Qualitative educational research (pp. 108-122). London: Routledge.

Harcourt, D., Perry, B., \& Waller, T. (Eds.). (2011). Researching young children's perspectives: debating the ethics and dilemmas of educational research with children. Abingdon: Routledge.

Hewer, C. T. R. (2006). Understanding Islam. London: SCM Press.

Heyneman, S. P. (2011). The corruption of ethics in higher education. International Higher Education, 62, 8-9.

Kelley, P. C., \& Chang, P. L. (2007). A typology of university ethical lapses: types, levels of seriousness, and originating location. The Journal of Higher Education, 78, 402-429.

Kum-Lung, C., \& Teck-Chai, L. (2010). Attitude toward business ethics: examining the influence of religiosity, gender and education levels. International Journal of Marketing Studies, 2(1), 225-232.

Lunenberg, M., Korthagen, F., \& Swennen, A. (2007). The teacher educator as a role model. Teaching and Teacher Education, 23, 586-601.

Maqsood, R. W. (2010). Islam: an introduction. London: Hodder Education.

Maxwell, B., Tremblay-Laprise, A., Filion, M., Boon, H., Daly, C., van den Hoven, M., Heilbronn, R., Lenselink, M., \& Walters, S. (2016). A five-country survey on ethics education in preservice teaching programs. Journal of Teacher Education, 67(2), 135-151.

Mukherji, P., \& Albon, D. (2015). Research methods in early childhood education: an introductory guide (2nd ed.). London: SAGE.

Niles, N. J., \& Barbour, K. A. (2014). Spheres of influence on Students' ethical decision making. Electronic Journal of Business Ethics and Organization Studies, 19(2), 10-16.

Punch, K. F., \& Oancea, A. (2014). Introduction to research methods in education (2nd ed.). London: SAGE.

Qur'ān (1997). Sahih International. Jeddah: Abul Qasim Publishing House. Available at http://quran.com/.

Rahman, A. (1980). Muhammad: the educator of mankind. London: The Muslim Schools Trust.

Reeder, J. (2011). Religion and morality. In P. B. Clarke (Ed.), The Oxford handbook of the sociology of religion (pp. 336-359). Oxford: Oxford University Press.

The Law Society (2015). Solicitor's Code of Conduct 2011. http://www.lawsociety.org.uk/supportservices/advice/articles/solicitors-code-of-conduct-2011/. Accessed on 14 Nov 2015.

Woofitt, R. (2008). Analysing accounts. In N. Gilbert (Ed.), Researching social life (pp. 287-395). London: SAGE.

Yunanda, R. A., \& Abd. Majid, N. (2011). The contribution of Islamic ethics towards ethical Accounting practices. Issues in Social and Environmental Accounting, 5(1/2), 124-137.

Zimmer, M. (2010). "But the data is already public": on the ethics of research in Facebook. Ethics and Information Technology, 12, 313-325. 